\title{
Persoalan-persoalan dalam Implementasi Otonomi Daerah
}

\author{
Arief Ramelan Karseno
}

Changing on hierarchy of bureaucracy as autonomous region law implementation has changed quality of public policy and has caused misunderstand on autonomous district finance. District needs a growing market and trade than a raising local income $(P A D)$.

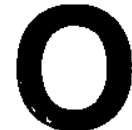

tonomi Daerah di Indonesia merupakan salah satu isu yang sangat mendominasi pembicaraan masyarakat Indonesia akhir-akhir ini. Munculnya pemikiran atas perlunya dilaksanakan otonomi daeráh bagi seluruh wilayah di Indonesia ini didasarkan atas macetnya sistem perekonomian Indonesia selama masa pemerintahan Orde Baru. Pada masa itu banyak sekali terjadi pelaksanaan pembangunan eknomi di daerah yang sama sekali tidak melibatkan partisipasi masyarakat lokal. Sebagai akibatnya, masyarakat di daerah, merasakan adanya ketidak-adilan pemerintah di Pusat (Jakarta). Ini bisa terjadi karena sistem perencanaan pembangunan selama masa itu dilakukan oleh pemerintah pusat, dalam hal ini Bappenas. Pada saat itu perencanaan oleh Bappenas sangat kurang melibatkan partisipasi masyarakat di wilayah pembangunan terkait. Sebagai akibatnya, banyak proyek dan kegiatan ekonomi yang tidak sesuai dengan kebutuhan masyarakat lokal. Hal ini telah terlalu banyak menimbulkan "mis-allokasi" sumber daya pembangunan dan menimbulkan banyak peluang untuk terjadinya korupsi di tingkat pemerintah pusat. Korban dari kesalahan ini semua adalah rakyat, yang pada masa pasca Orde Baru harus menanggung beban hutang dan kesalahan yang dilakukan oleh rezim sebelumnya.

Otonomi Daerah di Indonesia akan dimulai dengan diberlakukannya UndangUndang nomor 22/1999 tentang Pemerintah Daerah dan Undang-undang nomor 25/1999 tentang Perimbangan Keuangan antara Pemerintah Pusat dan Daerah secara penuh pada tahun.2001 yang akan datang. Undang-undang Otonomi Daerah ini pada awal April tahun 2000 ini mulai di-uji cobakan untuk pada akhirnya dilaksanakan secara penuh pada tahun anggaran 2001 yang akan datang. Dengan Otonomi ini, terjadi cukup banyak perubahan mekanis- 
me penentuan anggaran penerimaan dan Belanja Daerah, khususnya pada level daerah tingkat II (kabupaten).

Bersamaan dengan persiapan ini terdapat banyak perbedaan pendapat pro dan kontra otonomi daerah. Perbedaan pandangan itu pada umumnya terjadi antara kelompok masyarakat (pemerintah) yang merasa siap dan merasa tidak siap untuk melaksanakan otonomi daerah tersebut. Masyarakat dan pemerintah yang merasa bahwa daerahnya siap menghadapi otonomi daerah, pada umumnya adalah masyarakat daerah yang memiliki kekayaan sumber daya alam (SDA) yang cukup dan memiliki penduduk relatif sedikit. Sedangkan mereka yang cemas adalah mereka yang merasa miskin SDA dan berpenduduk padat. Tulisan ini akan membahas persoalanpersoalan didalam pelaksanaan Otonomi Daerah secara penuh.

\section{Perubahan Kelembagaan}

Perubahan pola pemerintahan dibawah UU no 22/1999 dan UU no. 25/1999, menimbulkan banyak pergeseran. Pada UU no 22/99 pergeseran yang terjadi meliputi perubahan hierarchyatau urutan kekuasaan birokrasi yang ada, antara pemerintah pusat dan daerah, serta antara legislative dan executive. Pergeseran hierarchy pemerintahan ini menimbulkan banyak persoalan dalam mencari equilibrium baru penentuan politik atas hal-hal yang berkaitan dengan kebijakan publik. Persoalan politik yang timbul antara lain adalah, terputusnya hubungan vertikal antara Bupati dengan Gubernur, dan berubahnya derajad kewenangan Pemerintah Pusat terhadap wakilnya di daerah (Gubemur). Gubemur yang dulu merupakan kepanjangan tangan kekuasaan pemerintah pusat sepenuhnya dan bertanggung-jawab kepada Presiden, sekarang berubah menjadi perwakilan pusat di Daerah yang bertanggung-jawab kepada DPRD. Dalam hal ini terjadi peningkatan kewenangan DPRD terhadap executive di Daerah Propinsi.

Di daerah otonom, Bupati/Walikota yang dahulu merupakan kepanjangan tangan Executive Pusat dan Propinsi di Daerah Kabupaten/Kota, sekarang harus bertanggung jawab kepada DPRD setempat.

Dengan adanya perubahan ini, hubungan kewenangan antara executive di Daerah Otonom dan di Pusat, menjadi terpisah sepenuhnya kecuali dalam bidang-bidang kewenangan yang masih dipegang Pusat sesuai dengan ketentuan pasal 7 (1) UU no 22/99, yaitu kewenangan dalam bidang politik luar negeri, pertahanan keamanan, peradilan, moneter dan fiskal, agama, serta kewenangan bidang lain. Secara umum dapat terlihat bahwa kewenangan pemerintah daerah (Bupati dan DPRD) menjadi jauh lebih besar dari sebelumnya. Peningkatan kewenangan DPRD terhadap Bupati juga menjadi sangat menonjol. Keputusan pemerintahan Kabupaten ditentukan secara terpisah dari keputusan pemerintahan Propinsi dan Pusat.

Perubahan hierarchy ini menimbulkan banyak konsekuensi. Apabila dimasa lalu kualitas keputusan publik yang diambil oleh Bupati dipertanggung-jawabkan kepada Gubernur (meskipun secara formal dibacakan di depan DPRD II), sekarang keputusan Bupati sepenuhnya dinilai oleh DPRD Kabupaten. Apabila dimasa lalu kualitas Gubernur akan menentukan kualitas kebijakan pemerintah, maka kualitas keputusan itu sekarang tergantung pada kualitas Anggota DPRD Kabupaten sepenuhnya. Maju dan mundurnya masyarakat tergantung kepada Bupati dan Anggota Legislatif di Kabupaten. Kalau dahulu banyak keputusan salah diambil oleh Bupati, maka sekarang keputusan salah adalah tanggung jawab DPRD juga. 
Pergeseran urutan kekuasaan seperti ini sedikit banyak telah menimbulkan ketegangan dan kekhawatiran banyak pihak, khususnya pejabat pemerintahan yang lama. Peningkatan peran DPRD yang jauh lebih tinggi dibandingkan pada masamasa yang lalu dihadapkan birokrat yang berpengalaman cukup lama, menimbulkan persoalan baru dalam penentuan anggaran dan jenis kebijakan publik yang harus diambil dan pada akhirnya dipertanggungjawabkan. Dalam masa transisi ini, Anggota Dewan Legislatif perlu memiliki wawasan birokrasi yang lebih luas untuk menyamakan "irama" pengambilan keputusan pemerintahan daerah. Apabila hal itu tidak dipahami, maka para Anggota Dewan Legislatif akan terlalu banyak merasa memiliki hak daripada memiliki kewajiban. Seperti banyak diketahui, menjalankan kewajiban memang jauh lebih sulit daripada menuntut hak.

Disisi lain, Anggota Dewan Legislatif juga memiliki kepentingan untuk memperpanjang karier politiknya, dengan melaksanakan tugas / kepentingan Partai atau Fraksi yang dibebankan kepadanya. Hal ini akan membawa konsekuensi, bahwa kebijakan Pemerintah akan mengarah kepada pembangunan infrastruktur bagi kepentingan Partai politik di Daerah Kabupaten yang bersangkutan. Kebijakan Pemerintah Daerah akan mencerminkan kebijakan orang-orang partai didalam Lembaga Legislatif. Persoalan yang timbul adalah apakah pemikiran Anggota DPRD dapat mencerminkan pemikiran rakyat yang memilihnya? Misalnya, keinginan masyarakat untuk memiliki jalan raya yang terawat baik, tetapi hanya akan membayar pajak yang murah bisa disuarakan oleh para anggota DPRD ini? Hal ini merupakan wacana baru yang kita, bangsa Indonesia, belum pernah mengalami sebelumnya. Baik buruknya hasil pembangunan daerah dengan model otonomi ini sangat tergantung kepada kualitas SDM Partai pemenang pemilu yang lalu dan keberanian Bupati / Gubernur untuk melakukan lobby demi kemajuan Daerah. Pada akhirnya, pola ini merupakan batu ujian bagi Pemerintahan Daerah Otonom.

\section{Otonomi Keuangan Daerah(?)}

Istilah otonomi Daerah sering dikaitkan dengan otonomi keuangan daerah. Istilah otonomi keuangan daerah ini sebenarnya tidak tepat, karena tidak pernah dan tidak akan pernah terjadi sebuah wilayah didalam sebuah negara kesatuan memiliki sistem keuangan yang otonom (apalagi $100 \%$ ). UU no 25/1999 adalah undang-undang yang mengatur Perimbangan Keuangan antara Pemerintah Pusat dan Daerah, bukan mengatur otonomi keuangan daerah. Kesalahan terminologi ini telah menimbulkan kesan yang sangat berlebihan tentang pengaturan keuangan di daerah. Disatu sisi, banyak orang merasa bahwa, dengan pelaksanaan UU no 22/99 dan UU no 25/99 sebuah daerah akan "bangkrut" dan dilain pihak, di daerah kaya SDA, orang merasa bahwa "otonomi daerah" akan membawa daerah mereka "merdeka" penuh dan berpisah dari negara kesatuan Rl secara ekonomi.

Semua pendapat itu tidak benar, tetapi sudah sangat mempengaruhi pemikiran para anggota Dewan Legislatif di Indonesia. UU nomor 25/1999 adalah undang-undang yang mengatur mengenai bagaimana alokasi sumber-sumber keuangan Pemerintah Pusat dan Daerah harus dilaksanakan. Hal ini tidak bisa diartikan sebagai pembebanan dana pembangunan kepada daerah otonom secara sendiri-sendiri. Keberadaan sistem keuangan pemerintah daerah, tidak bisa dilepaskan daerah sistem keuangan negara secara keseluruhan. Sebagaimana disebutkan dalam pasal 7 (1) UU no 22/1999, ke- 
wenangan moneter dan fiskal masih merupakan kewenangan pemerintah pusat dan bukan pemerintah daerah. Dengan kata lain, pemerintah daerah otonom tidak boleh menentukan beban pajak kepada masyarakat daerah secara semena-mena, bebas atau secara otonom, karena rakyat yang harus membayar pajak tersebut adalah rakyat Indonesia yang dilindungi oleh negara. Implikasi dari hal ini adalah, bahwa otonomi keuangan daerah hanya terjadi pada proses pengeluaran keuangan daerah, dan bukan proses penerimaan daerah. Pengeluaran keuangan daerah itu pun harus melalui pos-pos tertentu yang diijinkan dalam UU no 25/1999. Perbandingan proporsi keuangan sebelum dan sesudah diberlakukannya UU no 25/1999 dapat dilihat pada tabel (lampiran).

Dengan adanya otonomi pada (sebagian) mekanisme pengeluaran pemerintah ini, maka sebenarnya yang perlu menjadi perhatian utama pemerintah daerah dan DPRD adalah menentukan mekanisme perhitungan pengeluaran yang lebih effisien dan effektif. Dengan melakukan pengeluaran secara lebih tepat dan bermanfaat bagi masyarakat banyak, performance pemerintah dapat menjadi lebih baik, dan pertumbuhan ekonomi daerah otonom dapat lebih cepat terjadi.

Secara garis besar dapat dikatakan bahwa, kebijakan pemerintah daerah dalam melaksanakan otonomi daerah dapat dipandang baik, selama kebijakan itu tidak menimbulkan hambatan perdagangan bagi masyarakat sendiri dan bangsa Indonesia secara keseluruhan. Dengan kata lain, semua kebijakan lokal bagi peningkatan ekonomi baru bisa dinilai "benar" apabila kebijakan itu tidak menggangu pertumbuhan perekonomian nasiona! secara keseluruhan.

Dengan demikian, usaha peningkatan $P A D$ dengan cara meningkatkan pungutan di segala bidang, misalnya, bukanlah cara yang bermanfaat bagi masyarakat dan bangsa Indonesia secara keseluruhan. Malah sebaliknya kebijakan itu cenderung mematikan perdagangan rakyat dan bangsa Indonesia secara keseluruhan. Dan ini akan sangat bertentangan dengan prinsip-prinsi yang dikandung dalam Pembukaan UUD 45 , yaitu menciptakan masyarakat yang adil dan makmur. Oleh karenanya kebijakan seperti ini tidak boleh diambil oleh DPRD maupun pemerintah daerah otonom. Pemerintah daerah, pada prinsipnya tidak perlu meningkatkan tarif retribusi demi peningkatan penerimaan daerah, karena peningkatan tarif itu akan merugikan masyarakat. Yang perlu dilakukan adalah menumbuhkan pasar daerah, membuka jaringan perdagangan melalui penciptaan infrastruktur perdagangan, sehingga perekonomian meningkat dan retribusi menjadi besar.

\section{Kesimpulan}

1. Otonomi daerah adalah otonomi politik dan bukan otonomi dibidang ekonomi. Artinya perubahan yang terjadi dalam otonomi daerah terutama adalah perubahan proses pengambilan keputusan politik untuk menentukan jenis pelayanan publik bagi masyarakat. Otonomi dibidang ekonomi hanya terjadi pada proses penentuan pengeluaran (belanja) daerah saja.

2. Kebijakan pemburuan PAD yang berlebihan pada dasarnya adalah pembunuhan usaha rakyat yang sangat berbahaya.

3. Performance pemerintah daerah dan DPRD akan ditentukan melalui proses keputusan pelayanan publik yang effisien (irit) dan effektif (cucuk). Oleh karena itu yang diperlukan oleh para executif dan anggota DPRD adalah 
Topik: Persoalan-persoalan dalam Implementasi Otonomi Daerah, Arief Ramelan Karseno

memahami sistem penentuan anggaran yang effisien dan effektif.

4. Untuk mencapai keputusan yang effektif diperlukan pemahaman perencanaan ekonomi yang baik dan penentuan Standard Analisa Belanja Daerah yang tepat, sehingga tidak terjadi penghamburan dana secara berlebihan ke arah pengeluaran yang tidak bermanfaat bagi masyarakat.

5. Untuk meningkatkan kinerja Pemerintah, pemerintah perlu mengidentifikasi ulang kegiatan-kegiatan pemerintah yang bermanfaat dan yang tidak bermanfaat.

6. Swastanisasi sebagian kegiatan pemerintah daerah bisa dilakukan sebagai alternatif sumber penerimaan daerah.

\section{Daftar Pustaka}

Chu, Ke-young and Hemming, R, 1991, Public Expenditure Handbook, $A$ guide to Public Pulicy Issues in Developing Countrise International Monetary Fund, Washington.

Hyman, David.N, 1999, Public Finance, A contemporary Application of Theory to Policy, $6^{\text {th }}$ ed, The Dryden Press, Fort Worth, TX.

Shah, Anwar and Qureshi, Z, 1994, Intergovernmental Fiscal and Relations in Indonesia The World Bank, Washington DC. 
Topik: Persoalan-persoalan dalam Implementasi Otonomi Daerah, Arief Ramelan Karseno

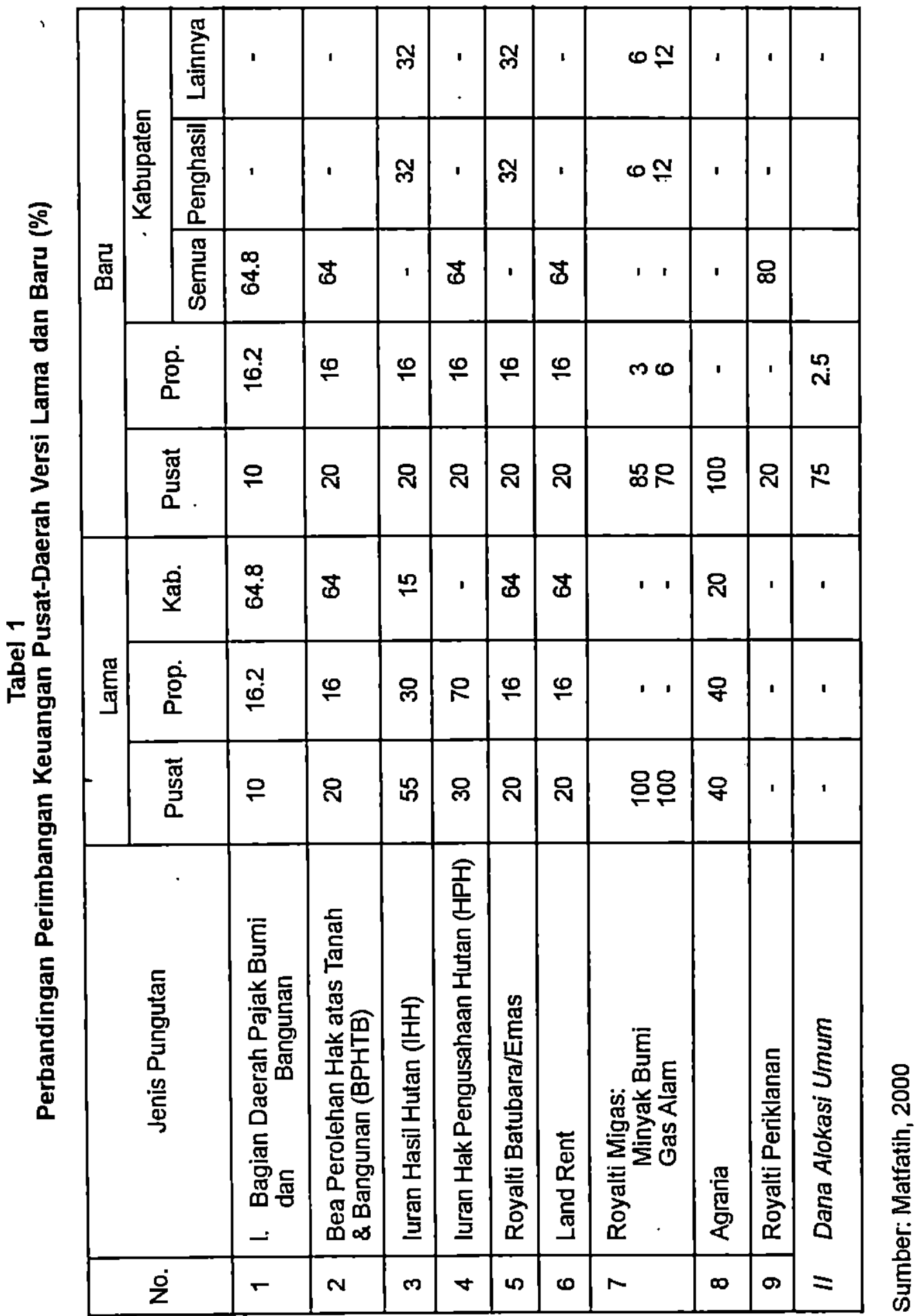

